Int.J. Hum. Soc. Dev. Res.

ISSN (P):2521-1439; ISSN (E):2523-4331

Volume 1, Number 2, 2017. 5-14

DOI:10.30546/2523-4331.2017.1.2.5

\title{
THE USE OF COMMUNICATION STRATEGIES IN ENGLISH LANGUAGE EDUCATION
}

\section{László KÁRPÁTI}

Eszterházy Károly University, Eger, Hungary

\author{
() The Author(s) 2017
}

\begin{abstract}
This paper examines the notion of communication strategies and their relevance to foreign language education, mainly in teaching English. Although our paper focuses exclusively on the usage of said strategies in the English language education, this does not mean that such strategies cannot be applied to the verbal performance of any other foreign language. We wish to emphasise the importance of the education of such strategies due to their nature of increasing verbal fluency which is a cornerstone of the current communicative approach. We present the different forms of such strategies and their possible applications in the language classroom while taking a glimpse at the current Hungarian language education.
\end{abstract}

(C)2017.All rights reserved

\section{ARTICLE HISTORY}

Received: 18/01/2017

Accepted: 16/06/2017

Published online: 05/10/2017

\author{
KEYWORDS \\ Communication strategies, \\ speech fluency, disfluency, \\ second language education, EFL \\ education
}




\section{Introduction}

The term Communication Strategies (or CS, for short), has been in the focus of SLA research since the 1970s. After its first appearance in Selinker's article on Interlanguage (1972) it has had a tremendous effect on a number of fields of research, including (but not limited to):

- bilingual/multilingual education

- foreign/second language acquisition

- language testing

- discourse analysis

- applied linguistics.

Due to its elusive nature, the term itself is hard to define in a clear-cut manner. As such, the following definitions have been suggested to describe the phenomena over the course of the years:

Communication strategies are «... mutual attempts of two interlocutors to agree on meaning in situations where the requisite meaning structures do not seem to be shared» (Tarone, 1980), or -potentially conscious plans\| (Faerch and Kasper, 1983). A recent interpretation by Maleki characterises CSs -... as an individual's attempt to find a way to fill the gap between their communication effort and immediate available linguistic resources\| (Maleki, 2007).

In our approach, communication strategies are a necessity for any student of a foreign or second language during communication, due to the high probability that they are presented with a linguistic and or cultural inadequacy when the conveyance of meaning occurs between one another. In other words, language users of (both) different linguistic and socio-cultural background are likely to apply these techniques during conversation if the phenomena of -communication breakdownll, i.e. the total inability to maintain a fluent and relevant conversation due to a certain lack of linguistic and cultural background information, is to be avoided. 


\section{Taxonomy of Communication Strategies}

In the 1970s, several studies set the foundations for the study of communication strategies. Selinker's (1972) article on interlanguage introduced the notion of second language communication strategies which was followed by Váradi's (1973) and Tarone's (1977) articles, in which both authors aimed at providing a systematic analysis of communication strategies. Their analysis was based on Selinker's notion of these strategies which claimed that: -if the fossilised aspects of interlanguage are the result of an identifiable approach by the learner to communication with native speakers of the target language, then we are dealing with strategies of second language communication\| (Selinker, 1972).

Váradi and Tarone later introduced a classification of communication strategies that would be used in subsequent research. However, according to Bialystok (1990), -the variety of taxonomies proposed in the literature differ primarily in terminology and overall categorizing principles rather than in the substance of specific strategiesll. This means that no matter what labels are used to name the same parts of a phenomenon, the core will remain the same.

\section{Types of CSs}

Communication strategies have five main categories and a number of subcategories which add up the following list:

A. Paraphrase

Paraphrase includes three subcategories which are:

(a) Approximation: The use of such native language (L1) vocabulary items or structures, that the language learner is aware of not being correct, but which shares certain semantic features with the desired item, thus satisfying the speaker's intention (e. g. a big rock instead of boulder, or pipe instead of water pipe).

(b) Word coinage: The learner is making up a new word - most often on the spot - in order to communicate a desired concept (e. g. airball for balloon or smoking leaf for cigar).

(c) Circumlocution: The learner describes the major characteristics or elements of an object, action or person instead of using the target language (TL) equivalent (e. g. She is, uh, smoking something. I don't know what's its name. That's, uh, Cuban, and they smoke it in other countries, too). 
B. Transfer

Transfer has two subcategories that are:

(a) Literal translation: The learner is translating word for word from L1 to L2 (e. g.

He invites him to drink. replacing They toast one another.).

(b) Language switch: The learner uses the L1 term without bothering to translate it into

L2 (e. g. léggömb instead of balloon or Verkehrsmittel replacing means of transport).

C. Appeal for Assistance

This refers to the learner asking for the correct term or structure from an exterior source of information, most likely a teacher or a fellow student (e. g. What is this? or How do you call that in English?).

D. Mime

Mime is related to the speaker using non-verbal strategies substituting an expression (e. g. clapping one's hands to illustrate applause, or rubbing one's eyes to indicate crying or tiredness, boredom).

E. Avoidance

Avoidance consists of two subcategories outlined below:

(a) Topic avoidance: The language learner is omitting concepts for which his/her vocabulary is lacking at the time of speaking.

(b) Message abandonment: The language user begins to talk about a concept but being completely unable to continue doing so due to a lack of phrases and expressions and thus ends up stopping in the middle of an utterance.

The above outlined typology of CSs is summarised in table 1, based on Tarone's work on the topic (Tarone, 1977).

\section{On the teachability of CSs}

Research on (foreign) language output (Mali, 2007; Maleki, 2007; Dörnyei and Thurrell, 1991, 1994; Tarone and Yule, 1989; Willems, 1987; Faerk and Kasper, 1986) shows that any form of language production is best learned through interaction. This is perfectly true for verbal interaction and communication strategies, as well. 
Since CSs are unconscious techniques their conscious realisation in any communicational situation demands a significant amount of practise and drilling. This practise was shown by Mali (Mali, 2007) to be an effective way of enhancing students language productivity, as far as verbal output is concerned. Mali also points out the fact that language teaching materials with communication strategies have a great potential in improving current language education.

As it was shown by the supporters of the theory (e.g. Dörnyei and Thurrell, 1991; Eszenyi, 2001; Maleki, 2007, 2010; Mali, 2007; Lewis, 2011), communication strategies can be and should be taught during foreign language education. One of the reasons to do so, is that they are part of what is known as communicative competence, creating the sub-branch of strategic competence (see Figure 2). The focus of the latter one is to use strategies (CSs) in order to avoid „communication breakdownsll. This phenomenon would most likely be categorised in Tarone's typology as the ultimate avoidance, where the speaker does not even attempt to start a conversation with the other (foreign) speaker.

In order to improve present day language teaching with the use of communication strategies Faerk and Kasper recommend the following three activities: communication games with visual support, without visual support, and monologues (Faerk and Kasper, 1986, 179 - 193). We would like to add here that the practice of the -one-minute monologuell about a given topic, or a favourite topic can also be considered here for improving speech fluency.

Another way of practising CSs usage is by using synonyms or antonyms: this can also act like a form of CS, since we can replace a word that is part of a fixed expression, e.g. in case of an idiom if the proper word is either unknown to us or the speaker cannot remember it at the time of speaking (e.g. it's no large deal, whereas big should be used instead, or it is a heavy decision instead of tough, or difficult).

As it is commonly known, language learners come across new vocabulary outside classrooms mainly in films and music (Kovacevic and Kovacevic, 2015). Citing lyrics or complete sentences that are borrowed from such artistic products and serve as a possible linguistic foundation for a likely reply also need to be regarded as a valid CS, because it allows the speaker to gain some time to plan the next move in the game of communication. 


\section{The current Hungarian scene}

Current foreign language education in Hungary still has issues with increasing speech fluency of its students, regardless of their level of study. As such, Communicative Language Teaching (CLT) needs to focus more on verbal communication and L2 output for conveying messages between one another, while not disregarding the other skills (reading, listening, writing). As such, teaching and using communication strategies should earn more appreciation within and without classrooms, since these techniques can actually enhance the verbal language output of each individual to a currently unknown extent.

The most ideal situation, for any language speaker would be that students practise the (freshly) acquired language outside the classroom on their own: either with their classmates or native speakers of English. Unfortunately, the latter can be seen as a form of privilege for some students, especially those living in rural Hungary, therefore, the use of online communication, language learning sites (e.g. Babbel.com, Memrise. com, or Duolingo.com) can act as a go-between for such SL learners until a native English speaker appears in sight.

\section{The place of CSs within the competence-based teaching model}

Since the foundation of communicative competence by Hymes (1972) and its application to L2 proficiency by Canale and Swain (1980) the competence-based model has undergone a number of changes. One such shift was placing cultural competence in the middle of the above shown figure in order to show that it was the primary element of the model (Bárdos, 2002).

However, regardless of the cultural component the model itself is invaluable for us because of its section, called strategic competence. This competence is the core of all communication strategies or evasion strategies. It is closely related to all competences within the triangle of discourse competence (see Figure 2), but it also act on its own, aiding in maintaining the fluency of speech and conversation throughout the whole process of speaking.

\section{The Role of CS in Language Education}

For these apparent purposes, a number of possible CS should be implemented in the language classroom. For instance, Willems (1987) suggests focusing on activities 
for practicing paraphrase and approximation (351-364). Brooks (1992) on the other hand, prefers circumlocution and appealing for assistance in education (59-71).

While there is no single CS that can be used in all possible situations with an unyielding efficiency, the possibility of combining these methods for a far better outcome than sticking to just one of them is ever-present. While circumlocution and paraphrasing require a larger and better organised mental vocabulary to work with, such techniques as miming, appealing for assistance or approximating are less demanding and serve the same goal, nonetheless.

We would like to refer to Rabab'ah (2005) research on the topic who claimed that teaching CS are beneficial for students for the following reasons:

First, usage of CS can lead to evoking previously forgotten vocabulary from both participants, especially when appealing for assistance. In our observation, the same can be said about circumlocution or paraphrasing as well as the use of synonyms and antonyms.

Second, by implementing such techniques, both parties have a greater chance of carrying on with their conversation, without losing face.

Finally, students can solve a communicational challenge on their own, while achieving their goal. (Rabab'ah, 2005, 194).

It must be also stated that by achieving the desired communicational goal on their own or be appealing for assistance, the usage of CSs has a high likelihood to lead to a more conscious use of language while boosting one's self-confidence adding to the autonomy of the students (Holec, 1981, Benson, 2001, Harmer, 2007).

\section{Conclusion}

Communication strategies are a crucial part of the competence-based language education system, as well as essential techniques for any fluent speaker of a (foreign) language within and without the language classroom. They are required for adding to the fluency of any speaker of a second or foreign language when the speaker is facing difficulties in verbal communication. In addition, they are both teachable and highly adaptable to the different study situations within and without a language classroom. As such, they are clearly worth the time invested in them, since achieving a greater speech fluency is a must in everyday communication in foreign language education and situations where spontaneous and quick replies (real-time action) is required. These techniques can be made personal by presenting a large number of methods from which the students themselves can choose their own personal favourite(s). Those presented with these techniques shall become less intimidated and more efficient speakers of a foreign language due to the mental and verbal arsenal standing behind them. 


\section{Disclosure statement}

No potential conflict of interest was reported by the author.

\section{Contact Information}

E-mail: karpati.laszlo@yahoo.com 


\section{References and notes:}

Bárdos Jenő (2002): A nyelvtani jelenségek mérése. In Földes Csaba (ed.): MMI. Annuum Tempus Linguarum Europae. Scripta Philologica Pannoniensis. Alkalmazott nyelvészet és nyelvpedagógia. Megemlékezés a „Nyelvek Európai Évérőlll. Veszprém, MTA VEAB-Veszprémi Egyetemi Kiadó, 81-94.

Bátyi Szilvia (2015): Foreign language attrition: elicited TOT phenomena. In Navracsics J. \& Bátyi Sz. (eds). Elsö- és második nyelv: Interdiszciplináris megközelitések. Pszicholingvisztikai tanulmányok VI. Budapest: Tinta Könyvkiadó, 47 - 61

Bialystok, E. (1990): Communication Strategies. Oxford: Blackwell, 195.

Brooks, F. (1992): Can we talk? Foreign Language Annals 25 (1), 59-71.

Dörnyei, Z. (1995): On the Teachability of Communication Strategies. TESOL Quarterly 29/1. 55-85.

Dörnyei, Z. \& S. Thurrell. (1991): Strategic competence and how to teach it. ELT Journal 45(1), 16-23.

Ellis, R. \& G. Barkhuizen. (2005): Analysing Learner Language. Oxford: Oxford University Press, 404.

Eszenyi Réka. (2001): Kommunikációs stratégiák a nyelvórán. Modern nyelvoktatás. VII. évfolyam, 4. szám, 59-71.

Faerch, C. \& G. Kasper. (1983): Plans and strategies in foreign language communication. In C. Faerch \& G. Kasper (Eds.), Strategies in Interlanguage Communication. London: Longman, 2060 .

Faerch, C. \& G. Kasper. (1986): Strategic competence in foreign language teaching. In G. Kasper (Ed.), Learning, Teaching and Communication in the Foreign Language Classroom. Aarhus: Aarhus University Press, 179-193.

Grace, H. C. L. (2013): Revealing the Effectiveness of Communication Strategies. ELT Conference, Taichung City, Taiwan.

Hymes, D. H. (1972): On communicative competence. In J. B. Pride \& J. Holmes (eds.):

Sociolinguistics. Harmondsworth: Penguin, 269-93.

Kellerman, E. (1991): Compensatory strategies in second language research: A critique, a revision, and some implications for the classroom. In R. Phillipson, E. Kellerman, L. Selinker, M. Sharwood Smith \& M. Swain (Eds.), Foreign/second Language Pedagogy Research. Multilingual Matters. UK: Clevedon, 142-161.

Kovacevic, K. C. \& Kovacevic, M. (2015): Monitoring speakers' L2 maintenance effort. In Navracsics J. \& Bátyi Sz. (eds). Elsö- és második nyelv: Interdiszciplináris megközelítések. Pszicholingvisztikai tanulmányok VI.. Budapest: Tinta Könyvkiadó 33 - 47

Littlemore, J. (2001): An empirical study of the relationship between cognitive style and the use of communication strategy. Applied Linguistics 22 (2), 241-265. 
Maleki, A. (2007): Teachability of communication strategies: An Iranian experience. System 35 (4), 583-594.

Maleki, A. (2010): Techniques to Teach Communication Strategies. Journal of Language Teaching and Research 1/5. 640-646

Mali, Z. O. (2007): Exploring communication strategy use by learners of Isizulu in Synchronous computer-mediated communication (S-CMC). Iowa University, USA.

Maryam.J. (2017): Teaching Grammar to Pakistani ESL learners and Essay Writing Skills: A Case study of COMSATS Lahore Undergraduates. International Journal of Humanities and Social Development Research.Baku, Azerbaijan.1/2.30-48

Oxford, R. L. (2001): Language Learning Strategies. In R. Carter \& D. Nunan (Eds.), Teaching English to Speakers of Other Languages. Cambridge: Cambridge University Press, 166-172.

Paribakht, T. (1985):Strategic competence and language proficiency. Applied Linguistics, 6 (2), $132-146$

Poulisse, N. (1993): A Theoretical Account of Lexical Communication Strategies. In: The Bilingual Lexicon. Robert Schreuder, Bert Weltens (eds.). Studies in Bilingualism, 6, 157.

Poulisse, N. (1994): Communication Strategies in a Second Language. In: The encyclopedia of language and linguistics. Vol. 2. Oxford: Pergamon Press, 620 - 624

Rabab'ah, G. (2005): Communication problems facing Arab learners of English. Journal of Language and Learning 3 (1), 194.

Salomone, A. \& F. Marshal (1997): How to avoid language breakdown? Circumlocution! Foreign Language Annals 30 (4), 473-482.

Schmidt, R. (1983): Interaction, acculturation and the acquisition of communication competence. In N. Wolfson \& E. Judd (Eds.), Sociolinguistics and Second Language Acquisition. Rowley: Newbury House, 137-174.

Tarone, E. (1977): —Conscious Communication Strategies in Interlanguage: a Progress Reportll. In: Brown, H. Douglas, Carlos A. Yorio and Ruth Crymes. (eds.). On TESOL'77. Washington D.C.: TESOL: $194-203$.

Tarone, E. (1980): Communication strategies, foreigner talk, and repair in interlanguage. Language Learning 30 (2), 417-431.

Tarone, E. (1984): Teaching strategic competence in the foreign language classroom. In

S. Savingnon \& M. Berns (Eds.), Initiatives in Communicative Language Teaching. Reading: Addison Wesley, 127-136.

Váradi, T. (1973): Strategies of target language learner communication: Message adjustment. Paper presented at the Vlth Conference of the Rumanian - English Linguistics Project, Timisoara. Published in $l R A l .18,1980,59-71$.

Váradi, T. (1983): Strategies of target language learner communication. Oxford: Blackwell

Willems, G. (1987): Communication strategies and their significance in foreign language teaching. System 15 (3), 351-364. 